\title{
Persistent local insulin allergy in a diabetic with chronic lymphatic leukaemia
}

\author{
P.H. Winocour ${ }^{1}$ and M. Haeney ${ }^{2}$ \\ Departments of ${ }^{1}$ Medicine and ${ }^{2}$ Immunology, Hope Hospital, Eccles Old Road, Salford M6 8HD, UK.
}

\begin{abstract}
Summary: A 75 year old maturity-onset diabetic developed persistent local allergy to insulin. She had coexistent asymptomatic chronic lymphatic leukaemia. All species of insulin provoked a recurrence of the allergy and attempts at hyposensitization and treatment of the leukaemia produced only marginal benefit. Administration of subcutaneous steroids with insulin relieved the problem, but could not be stopped without relapse. Immunological investigations suggested an immune complex-mediated hypersensitivity reaction to insulin. The later development of immune complex-mediated arthropathy tended to support this suggestion. The lack of histological and immunological evidence of an IgE-mediated reaction suggested that in this case the mechanism of insulin allergy and arthralgia was IgG mediated. We suggest that the chronic leukaemia was implicated in both processes by interfering with homeostatic mechanisms that normally prevent the development of autoallergic disorders.
\end{abstract}

\section{Introduction}

Allergy to highly purified insulins is uncommon (Rosenwasser, 1982). When sensitization to human insulin occurs in the absence of previous exposure (Garcia-Ortega et al., 1984; Blandford et al., 1982), prior use of bovine or porcine insulin is thought to be responsible. If insulin allergy does not respond to a switch to a less immunogenic preparation, hyposensitization (Backmann et al., 1982) or the simultaneous administration of steroids is usually successful (Wiles et al., 1983).

We describe a case of persistent local insulin allergy in woman with chronic lymphatic leukaemia. The later development of immune complex-associated polyarthritis and the clinical and laboratory findings may help to explain the pathogenesis of insulin allergy in this case.

\section{Case history}

A 75 year old diabetic woman, having been adequately treated with oral hypoglycaemic agents for 37 years, required insulin treatment for the first time in 1983. There was no history of exposure to previous insulin injections. She was known to have had ischaemic heart disease and asymptomatic chronic lymphatic leukaemia since 1977. There was no history of atopy. In February 1983 her total white cell count was

Correspondence: P.H. Winocour M.B., M.R.C.P.

Accepted: 8 April 1986
$44.2 \times 10^{9} / 1$ (97\% lymphocytes) and cell marker studies showed typical B cell chronic lymphatic leukaemia. Serum levels of immunoglobulins $G, A$ and $M$ were within the normal range and IgE was $<7 \mathrm{U} / \mathrm{ml}$ (upper limit normal $100 \mathrm{U} / \mathrm{ml}$ ). There was no evidence of a paraprotein by immunofixation or immunoelectrophoresis.

In March 1983 treatment with highly purified porcine insulin (Monotard) was commenced at a dose of 20 units/day. Two months later painful inflammatory reactions developed at the sites of injection: 1 hour after injection there was slight erythema and stinging which subsided over the course of 2 hours to be followed about 12 hours later by the development of a florid indurated palpable lesion. This reaction lasted for up to $\mathbf{4 8}$ hours and left a degree of tethering of the underlying dermis. A blood count revealed significant eosinophilia of up to $1.4 \times 10^{9} / 1$, without any change in total immunoglobulin levels or electrophoretic pattern. Her injection technique was satisfactory and the patient did not swab her skin with spirit before injection. Similar 'allergic' reactions were subsequently triggered by quick acting purified porcine insulin (Actrapid), purified beef isophane insulin (Neuphane), biosynthetic human soluble and isophane insulin (Humulin) but not by saline. Reasonable diabetic control on $\mathbf{3 0}$ units of insulin daily with glycosylated haemoglobin levels averaging $10 \%$ excluded significant insulin resistance.

The lesions were examined prior to biopsy: they were up to $10 \mathrm{~mm}$ in diameter, situated fairly deep, and

The Fellowship of Postgraduate Medicine, 1986 
hot and tender. A superficial skin biopsy did not reveal any specific cell infiltration. The patient refused a second deeper biopsy.

Raised levels of polyclonal IgG antibody to beef $(54.0 \mu \mathrm{g} / \mathrm{ml})$, porcine $(49.6 \mu \mathrm{g} / \mathrm{ml})$ and human $(48.2 \mu \mathrm{g} / \mathrm{ml})$ insulin were detected (Professor W.G. Reeves) but the total IgE and IgG4 levels, and porcine insulin specific IgE and IgG4 antibodies measured by radioallergosorbent testing (Dr T.G. Merrett) were normal.

The lymphocyte transformation response to phytohaemagglutinin and pokeweed mitogen was extremely poor; this was attributed to the low proportion of peripheral $\mathrm{T}$ lymphocytes and precluded further lymphocyte stimulation tests by insulin preparations.

The results of intracutaneous and prick testing to various substances are shown in Table I. Allergic responses were seen to all species of insulin and a sterilized zinc sulphate solution.

Hyposensitization with biosynthetic human isophane (Humulin, E. Lilly and Co) was attempted according to the method of Galloway \& Bressler (1978), but suppressed reactions for only up to 5 days, as did treatment with the antihistamine terfenadine. When $2 \mathrm{mg}$ of dexamethasone was added to a 1000 unit vial of Humulin isophane $(0.05 \mathrm{mg}$ dexamethasone per injection), the reactions became less severe, but the patient developed severe leg cramps which were attributed to the steroids, necessitating withdrawal. A short course of oral prednisolone suppressed the reactions but caused intolerable gastrointestinal side effects. She was thereafter managed successfully with $0.1 \mathrm{mg}$ dexamethasone subcutaneously with each insulin dose, and quinine sulphate, for the leg cramps.
Over a 4 month period levels of total insulin binding IgG fell from 54.7 to $32.4 \mu \mathrm{g} / \mathrm{ml}$, but levels of insulinspecific IgE and IgG4 antibody remained within the normal range throughout. Attempts to wean the patient off dexamethasone led to a recurrence of symptoms 12 months after they had started.

In view of the possibility that the chronic lymphatic leukaemia was linked to the insulin allergy, chlorambucil was started as 2 weekly courses of $10 \mathrm{mg} / \mathrm{day}$, repeated in 6 week cycles. During this period subcutaneous dexamethasone was withheld. Reactions returned on the legs and buttocks 3 weeks after completing the first 6 week cycle of treatment ( 2 weeks of chlorambucil and 4 weeks off, to monitor the response to treatment) and after subsequent courses of chlorambucil, despite achieving peripheral white cell counts of $10 \times 10^{9} / 1$ (30\% lymphocytes).

We were able to obtain a supply of zinc-free insulin and after a 2 week period off all subcutaneous steroids we again skin tested the patient, using the forearms as on the first occasion. There was a surprising lack of response to skin testing on the arms which may reflect a lack of sensitivity, although reactions were recurring on the legs and buttocks. As there was no immediate or delayed reaction to zinc sulphate we felt that zinc was unlikely to be a significant factor in this continued problem.

In December 1984 the patient was admitted to hospital with an acute polyarthropathy of unknown cause. Her coexistent chronic lymphatic leukaemia was well controlled. Viral antibody titres and blood cultures were unhelpful and an antistreptolysin 0 titre was at the upper limit of normal. C-reactive protein was greatly elevated at $187.5 \mathrm{mg} / 1$ (upper limit of

Table I Immediate and delayed responses to initial intracutaneous and prick testing with different insulin species and other preparations, before attempted treatment of the insulin allergy

\begin{tabular}{|c|c|c|c|}
\hline \multirow[b]{2}{*}{ Preparation } & \multirow{2}{*}{$\begin{array}{c}\text { Prick testing } \\
\text { Immediate } \\
(10 \text { minutes })\end{array}$} & \multicolumn{2}{|c|}{ Intracutaneous testing } \\
\hline & & $\begin{array}{l}\text { Early } \\
(1 \text { hour })\end{array}$ & $\begin{array}{c}\text { Delayed } \\
(48 \text { hours })\end{array}$ \\
\hline Saline diluent $0.9 \%$ & $0 / 0^{*}$ & $0 / 0$ & $0 / 0$ \\
\hline Phenol $0.005 \%$ & $0 / 0$ & $0 / 0$ & $0 / 0$ \\
\hline Cresol $0.005 \%$ & $0 / 0$ & $0 / 0$ & $0 / 0$ \\
\hline Zinc sulphate $(1 \mathrm{mg}) 0.01 \%$ & $5 / 5$ & $5 / 30$ & $5 \mathrm{~mm}$ induration \\
\hline Actrapid (porcine insulin) $0.2 \mathrm{U}$ & $5 / 5$ & $5 / 5$ & $5 \mathrm{~mm}$ induration \\
\hline $\begin{array}{l}\text { Humulin isophane (human insulin) } \\
0.2 \mathrm{U}\end{array}$ & $5 / 5$ & $5 / 25$ & $8 \mathrm{~mm}$ induration \\
\hline $\begin{array}{l}\text { Neuphane (bovine insulin) } 0.2 \mathrm{U} \\
\text { Monotard (porcine insulin) } 0.2 \mathrm{U}\end{array}$ & $5 / 5$ & $\begin{array}{l}5 / 10 \\
5 / 10\end{array}$ & $\begin{array}{l}6 \mathrm{~mm} \text { induration } \\
5 \mathrm{~mm} \text { induration }\end{array}$ \\
\hline Histamine & $10 / 10$ & $5 / 30$ & $10 \mathrm{~mm}$ induration \\
\hline
\end{tabular}

*Figures refer to extent of wheal/flare in mm, unless stated as extent of induration in mm. If data are missing, test was not performed. 
normal $7 \mathrm{mg} / \mathrm{l})$. The biochemical profile was within normal limits and no joint abnormality was detected radiologically. The erythrocyte sedimentation rate (ESR) was elevated at $85 \mathrm{~mm}$ in the first hour.

Immunological investigations showed antinuclear antibody of $\mathrm{IgG}$ class to a titre of $1 / 1000(78 \mathrm{IU} / \mathrm{ml})$ but double-stranded DNA-binding antibodies were not present. Rheumatoid factor was weakly detectable.

Serum IgA, IgE and IgM were within normal limits, but the IgG was elevated at $20.9 \mathrm{~g} / 1$ (normal range $8.0-18.0 \mathrm{~g} / \mathrm{l}$ ). Serum C3 was elevated at $1.72 \mathrm{~g} / \mathrm{l}$ (upper limit of normal $1.4 \mathrm{~g} / \mathrm{l})$ but $\mathrm{C} 4$ was within the normal range. Immune complexes were repeatedly detectable in significant amounts by the platelet aggregation method (titre 1/80; normal <1/20) (Haeney, 1981).

Treatment with acetylsalicylic acid produced a marked symptomatic improvement and repeat estimations one month later showed a fall in ESR to $22 \mathrm{~mm}$ in the first hour and absence of immune complexes. Antinuclear antibody was still present at a titre of $1 /$ 1000 but double-stranded DNA binding was now weakly positive at $26 \mathrm{U} / \mathrm{ml}$.

She has now had insulin allergy for over 3 years and subcutaneous administration of dexamethasone with insulin is still required to suppress local reactions.

\section{Discussion}

Previously described local allergic reactions to biosynthetic human insulin (Garcia-Ortega et al., 1984; Blandford et al., 1982; Backmann et al., 1982; Wiles et al., 1983) have usually been of the immediate hypersensitivity type and associated with elevation of insulin-specific IgE. Treatment has been successful and the condition short-lived. However, cell-mediated (White et al., 1983) and immune complex-mediated (de Shazo et al., 1977; Porter \& Hartman, 1970) hypersensitivity reactions to insulin have also been described. The presence of IgG antibodies specific to human, bovine and porcine insulins in the absence of similar specific IgE antibodies raises the possibility of an immune complex (Arthus type)-mediated skin reaction (White et al., 1983; de Shazo et al., 1977), and the later development of an immune complex acute polyarthropathy raises the possibility that both autoallergic phenomena had a 'common' pathogenesis.

The chronic local insulin allergy could be attributed to an immune complex-mediated hypersensitivity re-

\section{References}

ASKENASE, P.W. \& VAN LOVEREN, H. (1983). Delayed-type hypersensitivity: activation of mast cells by antigenspecific $T$-cell factors initiates the cascade of cellular action associated with her chronic lymphatic leukaemia. Chronic lymphatic leukaemia can be associated with autoimmune phenomena, such as Coombs' positive haemolytic anaemia, thrombocytopenia or aplasia due to the production of antibodies to stem cells, but the reason is unclear (Sameer, 1971). In one case of chronic lymphatic leukaemia and diabetes associated with insulin antibodies, insulin resistance developed rather than insulin allergy (Kansal et al., 1976). Acute polyarthropathy has also been demonstrated (Hollander \& McCarthy, 1976). It is therefore possible that the malignant B lymphocytes of her chronic lymphatic leukaemia could have produced IgG antibodies to insulin with subsequent immune complex formation. However, her IgG was polyclonal, with no detectable monoclonal protein by either immunofixation or immunoelectrophoresis. The chronic lymphatic leukaemia may still have been indirectly responsible for insulin antibody production by interfering with suppressor T lymphocytes, anti-idiotype responses, or other mechanisms which normally prevent antibody formation.

Alternatively, the biphasic nature of her allergy could have been due to mast cell/T cell interactions (Askenase \& Van Loveren, 1983) or to cutaneous basophil hypersensitivity (Mitchell \& Askenase, 1983). However, the skin biopsy did not show any degranulated mast cells or basophils in the dermis.

We have described a case of insulin allergy in a woman with chronic lymphatic leukaemia and suggest that the leukaemic process may have interfered with those homeostatic mechanisms that normally prevent the development of troublesome autoallergic disorders.

\section{Acknowledgements}

We are grateful to Professor W.G. Reeves for measurement of IgG to human, bovine and porcine insulin; to Dr T.G. Merrett for measurement of insulin-specific IgE and IgG4; to the staff of the Haematology Department, Hope Hospital, for helpful discussion and management of this case; and to Mrs G. Medlicott and Mrs J. Rostron for secretarial assistance. We also acknowledge the assistance of Eli Lilly and Co (Indianapolis, USA), Novo Laboratories (Denmark) and Miss J. Cantrill (Pharmacy Department, Hope Hospital) in obtaining insulin allergy testing kits. We thank Dr H. Cohen for permission to study a patient under his care.

Dr P.H. Winocour is supported by a grant from the North West Regional Health Authority.

interactions. Immunology Today, 4, 259.

BACKMANN, H., HASCHE, H. \& MEHNERT, H. (1982). Intradermal desensitization with human insulin (recom- 
binant DNA) in a patient with severe allergic skin reaction due to insulin. Diabetes Care, 5, 165.

BLANDFORD, R.L., SEWELL, H., SHARPE, P. \& HEARNSHAW, J.R. (1982). Generalized allergic reaction with synthetic human insulin. Lancet, ii, 1468.

DE SHAZO, R.D., LEVINSON, A.I., BOEHM, T., EVANS, R. \& WARD, G. (1977). Severe persistent biphasic local (immediate and late) skin reactions to insulin. Journal of Allergy and Clinical Immunology, 59, 161.

GALLOWAY, J.A. \& BRESSLER, R. (1978). Insulin treatment in diabetes. Medical Clinics of North America, 62, 663.

GARCIA-ORTEGA, P., KNOBEL, H. \& MIRADA, A. (1984). Sensitisation to human insulin. British Medical Journal, 288, 1271.

HAENEY, M.R. (1981). Tests for circulating immune complexes. In Techniques in Clinical Immunology, second edition, Thompson, R.A. (ed). p. 170. Blackwell Scientific Publications: Oxford.

HOLLANDER, J.L. \& MCCARTHY, D.J. (1976). Arthritis associated with haematological disorders, storage diseases and dysproteinaemias. In Arthritis and Allied Conditions, Hollander, J.L. \& McCarthy, D.J. (eds). p. 1303. Lea and Febiger: Philadelphia.
KANSAL, P.C., STROUD, R.M. \& BOSHELL, B.R. (1976). Free and total insulin levels in a patient with insulin-resistant diabetes mellitus and chronic lymphatic leukaemia: effect of prednisolone therapy. Metabolism, 25, 445.

MITCHELL, E.B. \& ASKENASE, P.W. (1983). Basophils in human disease. Clinical Reviews in Allergy, 1. 427.

PORTER, R.D. \& HARTMAN, C.R. (1970). Arthus reactions from insulin, association with lupus erythematosus cell phenomena. Journal of the American Medical Association, 214, 1884.

ROSENWASSER, L.J. (1982). Immunological reactivity to insulin: animals models and clinical syndromes. Clinical Immunological Reviews, 1, 311.

SAMEER, M. (ed) (1971). Acquired immune haemolytic disorders. In Immunological Diseases. Little, Brown and Co: Boston.

WHITE, W.B., DE MARTIN, S.A. \& YOSHIDA, T. (1983). Severe delayed inflammatory reactions from injected insulin. American Journal of Medicine, 74, 909.

WILES, P.G., GUY, R., WATKINS, S.M. \& REEVES, W.G. (1983). Allergy to purified bovine, porcine and human insulins. British Medical Journal, 287, 531. 